\title{
Como é estranho nunca termos falado da verdade
}

\author{
José Manuel Heleno
}

\section{Amigo João:}

Confesso que me parece estranho nunca termos falado sobre a verdade. $\mathrm{Na}$ certeza de que estamos já e sempre na verdade e que ela é uma dimensão intersubjectiva irredutível, estranho que a verdade em si mesma nunca tenha sido tema das nossas conversas. Não tanto esta ou aquela noção de verdade, mas a verdade que se pressupõe estar por detrás de qualquer uma delas. Há quem diga que a filosofia abandonou este território e se entregou de alma e coração ao sentido. Mas estou em crer que a verdade é qualquer coisa que habita todos os territórios e que, de forma algo presunçosa, se esforça ainda por lhes traçar as fronteiras colocando-se do lado de fora dos seus limites.

Tu sabes como é vertiginoso esse triângulo cujos vértices são a linguagem, o pensamento e a realidade. Mas o que me preocupa é o lugar que a verdade ocupa nele; perturba-me o modo como se entranha em cada vértice e se derrama por todas as arestas. É provável que tudo isto acabe por se relacionar com o facto da tua veia aristotélica pulsar cada vez que ouvias falar em Nietzsche, acusando-o de não ser suficientemente firme nos conceitos, ou então, o que era bem pior, de ser ridículo pensar que pode existir verdade-sem que os conceitos se apurem. Qka, apurar os conceitos é esforçarmo-nos por saber como é que a verdade se entranha no pensamento, na linguagem e na realidade.

Há, portanto, um apelo à firmeza dos conceitos - à sua verdade, direi eu. Essa firmeza que tu, apesar de tudo, sabes delicada e precária, embora essencial para a existência do pensamento e para que a filosofia se torne uma ciência de rigor. Ao lembrar-me das nossas conversas e ao reler os teus textos, encontro na noção de antepredicativo um terreno firme para o esclarecimento da noção de verdade. Sei que citaste obsessivamente o Da Interpretação do Aristóteles, nomeadamente o trecho que diz respeito à questão dos enunciados - apofânticos e hermenêuticos e te preocupaste com o juízo e com a relação entre sujeito e predicado. Fizeste disso o teu cavalo de batalha, teimando em alertar os filósofos e os aprendizes de filosofia que havia aí um filão que era importante explorar.

Foi então na noção de antepredicativo e de experiência que cerraste fileiras. Chamaste a ti Husserl e Heidegger, Gadamer e Jauss, preparado para falar da crise das ciências europeias, da distinção ontológica, da tradição ou da recepção estética, tudo isto girando em torno da noção de experiência. É certo que tinhas, cada vez mais, um olhar distanciado, recorrendo uma e outra vez a Aristóteles para pensar o que ainda não estava suficientemente pensado. Era essa, no fundo, a tua forma de seres livre. 
Ponhamos as coisas assim: a essência da verdade é uma questão voltada para o real. Não se trata de saber o que é verdadeiro neste ou naquele domínio, mas sim o que é a verdade na sua essência. Tu sabes que era deste modo que Heidegger iniciava Vom Wesen der Wahreit. Mas deixa-me dizer-te que aquilo que quero ler em Heidegger quero também ler em ti. Quero dizer-te que se a essência da verdade é a liberdade; se é a abertura primordial do homem ao ente, também a verdade da tua vida está inteira na liberdade, nesse modo de ser que te dispunha a abrir-te aos outros, a escutá-los e a viveres os teus dias praticando a verdade, quer dizer, em plena liberdade. O que tu puseste em prática foi a vivência intersubjectiva da verdade, algo que indicava a dimensão superlativa da comunicação que acabava por desaguar na hermenêutica, nessa necessidade de viver a interpretação porque a própria interpretação é uma forma de vida. Deixaste que a liberdade tomasse conta de ti e te possuísse.

Podias, assim, fazer de cada dia o último; porque se faz de cada dia o último se assumirmos a liberdade de ser. E se a liberdade é o deixar ser os entes; se é esse estado de aberto que cria a verdade, tornamo-nos verdadeiros quando somos livres. E era espantoso o modo como oferecias a tua imensa liberdade ao mundo, o que nos permite compreender porque viveste dentro da verdade. Direi ainda que transitaste da ideia de verdade enquanto conformidade entre o enunciado e a coisa para uma noção que nos ajuda a entender tal conformidade, justamente o que está por detrás dela e faz aparecer a coisa e aquilo que se diz dela. E por isso que a verdade não pode residir originariamente na proposição.

Sei, no entanto, que te perdias vezes sem conta; que vagueavas e te tornavas errante. Parecias então não seres verdadeiro, ou seja, passavas ao lado das coisas e não te entranhavas nelas, acometido por uma cegueira que te subjugava. Contudo, devo relembrar que era ainda Heidegger que falava na não verdade como errância como um passar ao lado do mistério. Ora, tu ocultavas as coisas e ocultavas-te a ti mesmo nesse gesto. Sabe-se, aliás, como esse gesto de ocultamento não é estranho à essência da verdade, quer dizer, se esta é desvelamento é porque habita no seu intimo a possibilidade de ocultar, algo que permite fecharmo-nos aos entes e mergulharmos no bom senso comum. É por isso que o teu lado errático não era contrário à liberdade de ser verdadeiro, era antes a possibilidade mesma de te tornares livre e poderes, enfim, desvelar e conhecer-te quando encontravas o ente em liberdade.

É por isso que a urgência em conhecer a verdade não tem apenas um carácter metafísico ou ontológico, tem também um carácter político, pois relaciona-se com a intersubjectividade e com a nossa forma de agir. Há, por conseguinte, uma pluralidade de saberes sobre a verdade, e cada um deles tenta apanhá-la nas suas malhas. Com efeito, se queremos conhecer a essência da verdade teremos que mergulhar no pensar e no agir, enfim, na própria experiência. Teremos que mergulhar na história de que somos feitos e, por maioria de razões, no facto de sermos já e sempre com os outros. É convicção minha que tu vivias efectivamente esta dimensão da verdade - e que era ela, aliás, que te permitia abraçar a hermenêutica e acentuar não apenas o espaço da amizade como também dar atenção à política, ou seja, atender ao modo como os homens se definem na sua relação com os outros. Tu sabias que era urgente fazer um uso público da verdade.

Como dizia Hannah Arendt - alguém que nunca referimos nas nossas conversas -, é premente chamar a atenção para as verdades de facto. E é a autora de Truth and Politics que quero agora mencionar para que o próprio Heidegger tão próximo e tão distante dela! - possa ser lido de outra forma. É assim que somos conduzidos para um terreno que Heidegger nunca quis pisar enquanto filósofo, ou 
seja, o terreno das relações entre verdade e política, ou antes, das más relações entre ambos. E não deixa de ser extraordinário como, ao longo da história da filosofia, se teima em opor a verdade à opinião - isso que era o desejo de Parménides e que alastrou por vários séculos. Também Platão, na sua alegoria da caverna, reforçava essa oposição entre verdade e opinião - e até o próprio Heidegger não se esquiva a esta atitude que tem o seu quê de metafísico. No entanto, o que Hanna Arendt defendia era a necessidade de repensar a oposição entre verdade e opinião e o facto de o filósofo, ao querer descobrir princípios que fundamentavam a política, acabar por lastimar a opinião e a ignorância dos cidadãos. Mas não há, efectivamente, exercício de cidadania que não se apoie na opinião, e é neste sentido que ela pode ser reabilitada.

Se a verdade se opõe à mentira e ao erro, mais do que à ignorância ou à opinião, isso significa que as verdades de facto devem ser encaradas com seriedade, pois há sempre um perigo que nos espreita quando afastamos a verdade da política. Se teimarmos em dizer que não há verdades de facto, é a história e a política que se ressentem; é ainda a própria verdade que se gasta e se atrofia ao insistirmos em dizer que não há factos sem interpretação. Não há verdade que se aguente com tais excessos.

Quando Heidegger «esqueceu» o político em Sobre a Essência da Verdade, esqueceu o facto de a verdade ter um domínio público. Como escreve Arendt - nesse texto que poderia servir de paradigma como resposta ao autor de Sein und Zeit -, «nenhuma permanência, nenhuma persistência no ser podem sequer ser imaginadas sem homens querendo testemunhar aquilo que é e lhes parece ser porque é». Isto, parece-me, abre uma frecha na ideia que a verdade tem de ser «desinteressada»; e que a ciência e a filosofia são exemplos dessa pureza desinteressada. O que devemos interrogar é, porém, o significado de «desinteresse» da verdade na actividade política. É que a política não poderá existir sem verdades de facto, embora se esforce vezes sem conta por escamotear e iludir esta asserção. Escreve ainda Arendt que «a liberdade de opinião é uma farsa se a informação sobre os factos não estiver garantida e se não forem os próprios factos o objecto do debate». A verdade tem que ter poder no domínio público. Se os factos são a matéria da opinião, esta tem o poder de os falsear ou de os omitir. E se eu falo aqui na política e na sua verdade é porque não me esqueço da forma como viveste e sentiste a dimensão intersubjectiva do ser verdadeiro.

No entanto, se as verdades politicamente mais importantes são as verdades de facto, como é que Heidegger, por exemplo, responderia a esta afirmação? E quando o prisioneiro de Platão se liberta da caverna, que tipo de verdade é essa que ele defende? Não uma verdade de facto, mas uma verdade que é uma «visão do mundo», talvez mais perigosa do que as simples verdades de facto. Platão imagina os prisioneiros da caverna presos às sombras, aos sentidos, numa palavra, ao senso comum. E foi assim que essa aventura que opôs verdade e opinião se sedimentou, opondo um mundo inteligível a um mundo sensível. Se lermos o texto de Heidegger sobre a essência da verdade à luz de Platão, veremos que não é descabido descobrir as pegadas do «platonismo».

É por tudo isto que me interrogo sobre o que é que levará alguns de nós a perseguir a verdade. Donde nos vem a paixão por ela? Quer dizer, o gosto pela ontologia, pela ética, pela política - e é inegável que a verdade mora em cada uma destas regiões. O que eu sei, amigo João, é a que a nossa conversa ficou inacabada. Sei que a tua noção de experiência estava presente em cada uma destas regiões, nesse mapa que completavas e aperfeiçoavas enquanto te exercitavas em ser livre. Mas o que me cativa neste mapa é que ele pode ser aberto e lido por qualquer um - 
e é por isso, justamente, que é um mapa. Nómada, procuraste orientar-te enquanto deambulavas; procuraste descobrir clareiras num bosque quase impenetrável. E é nessa vagabundagem que, afinal, descobres a tua liberdade, algo ainda mais antigo do que qualquer verdade. Mas não só. Acabas também por nos confiar que a verdade também é política, e que é preciso redobrar a vigilância para que a mentira não destrua de vez a relação entre os homens. E é por tudo isto, digo, que só aparentemente é estranho nunca termos falado da verdade, pois a tua vida e aquilo que dela fizeste foi uma forma de lhe dar sentido e de nos ajudares a pensá-la de outra forma. Podemos falar de milhares de coisas, mas nada é tão importante como aquilo que se faz e se oferece como testemunho.

Não sei exactamente o que é que se pede a uma vida. Que ela seja ou não virtuosa; que seja ou não justa, penso que se apresenta sempre como um testemunho. É neste sentido que ela acaba por ter sempre a «sua» verdade. E é também por isso que a contingência não lhe retira o valor, antes a engrandece. Entre a liberdade e a errância, e a fronteira turva que separa uma da outra, traçaste o teu caminho. E é aí que a vida, sempre irresolúvel e fugidia, mostra o seu rosto, pois até no que se cala habita a verdade.

Terminarei dizendo que é muito difícil falarmos daquilo que os outros pensam. Quando os conhecemos de perto é aquilo que eles são que nos impressiona, quer dizer, a forma como se dão e se tornam corpo - plena visibilidade que a palavra e os gestos nos oferecem. A verdade passa por aqui como uma espécie de música que, sem imagens nem conceitos, assume marcas indeléveis. Mais do que dar o nome de verdade a esta forma do outro aparecer, talvez seja preferível aceitá-la como uma dádiva de alguém que teve a coragem de existir em liberdade. 